\title{
EFFECT OF PROCESSING ON VITAMIN A AND SOME MINERAL CONTENTS OF PUMPKIN (Cucurbita maxima) SEED
}

\author{
Ambi, A.A. ${ }^{1 *}$, Bashir, M. ${ }^{2}$, Hafsat, B.M. ${ }^{1}$, Nura, M. ${ }^{1}$, Abubakar, $\mathrm{H}^{1}$ and Shatu, $\mathrm{M}^{1}$. \\ 1. Department of Science Laboratory Technology, Federal Polytechnic Bauchi. \\ 2. Centre for Dryland Agriculture, Bayero University Kano. \\ *Corresponding author: ahmadambi@fptb.edu.ng +234 7033421992
}

\begin{abstract}
Pumpkin (Cucurbita maxima) seeds are important food materials used by most Nigerian families due to their delicious taste, aroma and appeal. In this study, changes between chemical composition of processed and unprocessed pumpkin seeds (Cucurbita maxima) was investigated. The nutritional compositions were analyzed by standard methods. The vitamin $A$ contents of the processed and unprocessed pumpkin seed were found to be $36.83 \mu \mathrm{g} / 100 \mathrm{~g}$ and $33.72 \mu \mathrm{g} / 100 \mathrm{~g}$ respectively. The copper, zinc, magnesium, phosphorus and iron contents of processed seeds were; $0.063,0.43,47.67,58.19$ and $610.77 \mathrm{ppm}$ respectively while the values for unprocessed were; $0.047,0.41,36.73$, 58.45 and 211.19 ppm respectively with significant difference between the processed and unprocessed. The finding suggests that pumpkin seed is rich in this vitamin and minerals. If utilized efficient/y. It can also ameliorate micronutrients deficiency problem in population of all age groups.

Keywords: Pumpkin seed, Cucurbita maxima, vitamin A, nutrition, processed, unprocessed
\end{abstract}

\section{INTRODUCTION}

In the maintenance of healthy life, food is one of the unique requirement without which the body can't fight diseases easily. In the present pandemic of COVID-19, boosting immunity is one of the measures taken to curtail its progress and managing of exposed individuals. Food processing aids in making nutrients such protein, carbohydrates, minerals, vitamins accessible at the same time reducing some of the negating nutrients i.eanti-nutritional factors. Different plants parts namely leave, stem, roots and seeds contain various amounts of nutrients and antinutrients (Elinge et al., 2012).

Curcubita maxima (pumpkin), a medium sized plant from the Cucurbitaceae is grown for its fruits and seed for human consumption. Qamaret al. (2019) have highlighted the tilt in recent years towards the seeds of pumpkin due to its nutritional and medicinal applications. The seeds of this plant that have unique flavor and nutty taste is consumed salted or as a roasted snack in some parts of the world; Canada, USA and Nigeria. It is also sold fermented, sprouted, baked among other forms because of its rich content of proteins, minerals such as manganese, magnesium, zinc, potassium, copper, phosphorus, PUFA (polyunsaturated fatty acid), tocopherol and carotenoids.

Many countries; India, Brazil, Mexico and China, are using pumpkin in traditional medical practicesin addition to its protein, mineral, vitamins and antioxidant potentials (Karanja et al., 2013).

Vitamin A (beta carotene), a fat soluble vitamin, present in food, participates in retarding the ageing process, reduces tumor progression and development of cataract. Other important parts played by vitamin $A$ is strengthening the immune system and making it an important requirement in food most significantly in the present covid-19 pandemic. It also helps in proper functioning of the heart, kidneys and other organs. The consumption of food that is rich in beta carotene, have been reported to lower individuals risk of certain kinds of cancer that include lung, prostate (NIH 2019).

The rich content of micro and macro element is another relevance of this seed. The numerous functions of zinc in the body can be seen in such biochemical processes of healing, improving immune system and tissue maintenance. It is also required in DNA synthesis. Iron as an essential trace element is important for growth and survival of most living organism (Jaishakaret al. 2014).

In addition, it is a major factor in plant oxidation and reduction reactions. The structures of cytochromes, hemes and the electron transfer system are only efficient and complete when iron is part of it. In systemic management of lead, iron in hemoglobin assist greatly(Jain et 
BAJOPAS Volume 13 Number 2, December, 2020 al., 2005). The main role of iron is in hemoglobin formation in red cells that are responsible for oxygen carrying and transport. Manganese is part of many biochemical processes where it helps many enzymes system such as thiamine, biotin and vitamin C (Leitari and Meiyanto 2018). It also helps in the metabolism and utilization of proteins, fatty acids and cholesterol (Reilly et al., 2002).

Another important element in many plant enzymes is copper because it involved in many electron transfer processes, nerve conduction, immune and cardiovascular systems. Copper is also a part of estrogen metabolism and maintenance of pregnancy (Thompson et al., 2017).

Various chemical reactions are induced by roasting. Yoshida et al., (2005) reported that polyunsaturated fatty acids in vegetable oil is higher, the rate of quality deterioration of the oils to roasting was the greater. Besides, tocopherols are particularly sensitive to heating at high temperatures (Barrera-Arellano et al., 2016). As a result, most tocopherols are lost or destroyed during the roasting (Francois et al., 2012). Some reports suggest that nutrient retention is improved during roasting (Gould and Golledge 1989), however other studies indicated that nutrient retention is not much greater than that of unroasted seeds (Thompson et al., 2017).

Hence, the availability of these factors, are either enhanced or diminished by the preconsumption processing approach. This study evaluates the vitamin A and elemental composition of the most commonly used forms of pumpkin seeds i.e the roasted and unroasted forms.

\section{MATERIALS AND METHODS}

\section{Sample collection}

The pumpkin seeds were purchased from Dawanau market in Kano, situated at12 ${ }^{\circ}$ 05' $12.38^{\prime \prime} \mathrm{N}, 8^{\circ} 26^{\prime} 27.99^{\prime \prime} \mathrm{E}$ in the month of September 2019. It was sorted clean and stored in an airtight bag.

\section{Materials/Instrument}

Microwave plasma Atomic Emission Spectrophotometer (Agilent 4200 MP-AES) UVVis spectrophotometer LT-291/Labtronics, digestion flask, whatman filter paper No 1, muffle furnace (STXMF-1119/Genlab) and Kjeldahl apparatus.

\section{Sample preparation}

The pumpkin seeds were dried at room temperature and divided into two portions. The first half was roasted while the second half was left as unroasted. The sample were pulverized separately into fine powder. This was then stored in an airtight bag for further analysis.

\section{Sample digestion}

The digestion was carried out according to the AOAC 1984 method. Briefly, $2 \mathrm{~g}$ of a sample was weighed into a clean beaker and digested with $15 \mathrm{ml}$ of nitric acid and $10 \mathrm{ml}$ of hydrochloric acid. The mixture was heated for an hour to $120^{\circ} \mathrm{C}$. It was allowed to cool, filtered and made to $100 \mathrm{ml}$ mark with distilled water.

Microwave plasma atomic emission spectrophotometer analysis.

All measurements were performed as described by Wei Li et al., (2013) with somemodifications using Agilent 4210 MP-AES. The sample introduction system consisted of PVC peristatic pump tubing (white/white and blue/blue), a single pass cyclonic spray chamber and the oneNeb nebulizer. The Agilent MP Expert software was used to automatically subtract the background signal from the analytical signal. A background spectrum from a blank solution was recorded and automatically subtracted from each standard and sample solution that was analysed.

Also the software was used to optimize the nebulization pressure and the viewing position for each wavelength selected to maximize sensitivity. Because of this optimization, and considering that all determinations were carried out sequentially, each analyte was determined under optimized conditions.

A standard reference solution was used to quickly and easily optimize the parameters.Calibration standards were prepared from stock solutions of iron, magnesium, zinc, phosphorus and copper. The intensities of the standards, roasted and unroasted samples were measured using MP-AES 4200 spectrophotometer. The corresponding intensities for each standard was automatically plotted against its concentration for calibration. Sample response was compared directly with the calibration curve.

Extraction and determination of vitamin A Vitamin A (Beta carotene) was determined by first soaking $1 \mathrm{~g}$ of the sample in $5 \mathrm{ml}$ of methanol for 2 hours at room temperature in the dark. The beta carotene layer was obtained by the addition of hexane in a separating funnel. The volume was made up to $10 \mathrm{ml}$ with diethyl ether and then this layer was passed through sodium sulphonate to remove moisture from the layer. The absorbance of the layer was measured at $436 \mathrm{~nm}$ using diethyl ether as blank. The beta carotene was calculated according to Rodriguez-Amaya et al., (2004). 


$$
\begin{aligned}
& \text { Beta Carotene }\left(\mu \frac{\mathrm{g}}{100 \mathrm{~g}}\right) \\
& =\text { Abs }(436 \mathrm{~nm}) \times V D \times 100 \times \frac{100}{W} x Y
\end{aligned}
$$

Where $\mathrm{V}=$ Total volume, $\mathrm{D}=$ Dilution factor, $\mathrm{W}$ = Sample weight, $\mathrm{Y}=$ percentage dry matter content of Sample.

\section{Statistical analysis}

Data from triplicate analysis for the same sample were subjected to student t-test. Means were separated at the significance level of $p<0.05$. The statistical analysis was performed using SPSS version 2.0 .

\section{RESULTS AND DISCUSSION}

The findings for Vitamin $A$ and mineral composition of processed and unprocessed pumpkin seed are presented in Table 1. From the table, a significant increase in vitamin A content between processed and unprocessed seed was observed. Vitamins are group of organic compound that are essential for normal growth and nutrition. They are also required in small amounts in the diet (Bardaa et al., 2016).

In a similar way, the magnesium and copper content of the processed pumkin seed are significantly higher than unprocessed seeds. Magnesium is necessary for the release of parathyroid hormone and for its action in the backbone, kidney and intestine and for the reactions involve in converting vitamin $D$ to its active form. Magnesium is important in tissue respiration, especially in oxidative phosphorylation leading to formation of Adenosine triphosphate (ATP). It is also involved in normal muscular contraction; calcium stimulates muscles while magnesium relaxes the muscles. Magnesium deficiency results in uncontrollable twisting of muscles leading to convulsion and tetanus, which may both lead to death (Rodriguez et al., 2014).

Table 1; Vitamin A and some mineral composition of treated and untreated pumpkin seed

\begin{tabular}{lll}
\hline Parameter & Treated pumpkin seed & Untreated pumpkin seed \\
\hline Vitamin A (pg) & $36.83 \pm 0.005^{\mathrm{a}}$ & $33.72 \pm 0.013^{\mathrm{b}}$ \\
Magnesium (ppm) & $47.67 \pm 0.0080^{\mathrm{a}}$ & $36.73 \pm 0.0005^{\mathrm{b}}$ \\
Iron (ppm) & $610.77 \pm 0.021^{\mathrm{a}}$ & $211.19 \pm 0.011^{\mathrm{a}}$ \\
Zinc (ppm) & $0.43 \pm 0.0005^{\mathrm{a}}$ & $0.41 \pm 0.0004^{\mathrm{a}}$ \\
Phosphorus (ppm) & $58.19 \pm 0.05^{\mathrm{a}}$ & $58.45 \pm 0.153^{\mathrm{a}}$ \\
Copper (ppm) & $0.063 \pm 0.0001^{\mathrm{a}}$ & $0.047 \pm 0.00005^{\mathrm{b}}$ \\
\hline
\end{tabular}

Mean \pm SD, values with same superscripts are statistically not different ( $>0.05)$, while values with different superscripts are statistically different $(p<0.05)$.

The iron, zinc and phosphorus contents of the processed pumpkin seed are on the other hand not statistically higher than the unprocessed seeds. Zinc is known for boosting the health of our hair. Payne, 1990 have documented its role in the proper functioning of some sense organs such as ability to smell and tastes. Zinc is also very important in protein and carbohydrate metabolism and also helps in mobilizing vitamin A from its storage site in the liver and facilitates the synthesis of RNA and DNA necessary for cell production.

Phosphorus is found bound to other substances especially in the blood and cells. It occurs in its inorganic form in nucleic acids, sugar phosphate and ATP which forms part of the non-skeletal phosphorus (Payne 1990). Phosphates play important roles as buffers that prevent change in the acidity of body fluids because of their ability to combine with additional hydrogen ion. The addition of phosphates to sugar is an important step in carbohydrates metabolism because it makes it possible for such nutrients to cross the cell membrane (Guthrie 1989).

Minerals are essential factors for proper functioning of the body system because they act in differing ways to improve enzyme activities, immune strength and uptake of vital molecules. The findings of the present studies suggest that pumpkin seed is rich in minerals such as magnesium, iron, zinc, phosphorus and copper (Aljahani and Cheikhoudman 2017).

The treatment has resulted in increase in some of the minerals. Similar findings were recorded where; Badifu (2001) reported that the contents of oils increased $3-7 \%$ in all Cucurbitaceae species. Due to the increase in the volume of intercellular spaces, oils were released from lipid bodies during heating (Ekpete et al., 2013). As for Artik (2004), the increase of oil content in hazelnut with roasting, proceeded from increase of oil content concentration due to the loss in moisture.

\section{CONCLUSION}

The results of the present study suggest that pumpkin seeds are rich sources of nutrients. It also shows that processing affects the level of various nutrients in pumpkin seeds. Therefore processing the pumpkin seeds before consumption is encouraged. 
BAJOPAS Volume 13 Number 2, December, 2020

\section{REFERENCES}

AlJahani A., and Cheikhousman R. (2017). Nutritional and sensory evaluation of pumpkin based (Cucurbita maxima) functional juice. Nutr. Food Sci; 47:346-356

AOAC (1984) Official method of analysis of the association of Official Analytical Chemisit. $14^{\text {th }}$ ed. Washington DC

Artik, N (2004) Turk Findiklarin Fenolikbilesikdagilimivekavurmaproselindede gisimi. Project No: 2002-07-11-045 Kesinsonuc Raporu, 96

Badifu GIO (2001) Effect of processing on proximate composition, antinutritional and toxic contents of kernels from Cucurbitaceaespecies grown in Nigeria. Journal of Food Composition and Analysis. $14,153-161$

Bardaa S., Halima N.B., Aloui F., Mansour R.B., Jabeur H., Bouaziz M., and Sahnoun Z. ( 2016). Oil from pumpkin (Cucurbitapepo L.) seeds: evaluation of its functional properties on wound healing in rats. Lipids Health Dis. 15:73-84.

Barrera-Arellano D, Ruiz-mendez V, Velasco J, Marquez- Ruiz G,Dobarganes C. (2002) Loss of tocopherols and formation of degradation compounds at frying temperatures in oils differing in degree of unsaturation and natural antioxidant content. J. Sci. Food Agric. 82, 1696-1702

Dong V. H., Ngoc M. P., Andy H. L., Duong N. T., Colin W. B. (2018). Dietary carotenoid intakes and prostate cancer risk: A casecontrol study from Vietnam Nutriens10(1):70-81

Ekpete O.A., Edori O.S., Fubara E.P. (2013).Proximate and mineral composition of some Nigerian fruits. Br. J. Appl. Sci. Technol. 3:1447-1454.

Elinge C. M., Muhammad A., Atiku F. A., Itodo A. U., PeniI. J., Sanni O. M. and Mbongo A. N. (2012). Proximate, Mineral and Anti-nutrient Composition of Pumpkin (Cucurbitapepo L) Seeds Extract. International Journal of Plant Research 2(5): 146-150 DOI: $10.5923 /$ j.plant.20120205.02

François G, Nathalie B, Jean-Pierre V, Daniel P, and Didier M (2006) Effect of roasting on tocopherols of gourd seeds (Cucurbitapepo).Grasas Y Aceites. 57 (4), 409-414

Gould MF, and Golledge D (1989) Ascorbic acid levels in conventionally cooked versus microwave oven cooked frozen vegetables. Food Sci. Nutr. 42: 145-152

Guthrie, H. A. (1989). Introductory Nutrition (7th ed.). Time mirror Mosby college publishers, Boston.

Jaishankar, M., Tenzin, T., Naresh A., Blessy B. M., and Krishnamurthy NB. (2014). Toxicity, mechanism and health effects of some heavy metals. Interdisciplinary Toxicology 7(2): 6072

Jian L, Du CJ, Lee AH and Binns CW (2005). Do dietary lycopene and other carotenoids protect against prostate cancer?
International Journal of

Cancer, 113(6):1010-1014

DOI: 10.1002/ijc.20667 PMID: 15514967

Karanja, J.K., Mugendi, B.J., Khamis, F. M. and Muchuji, A. N. (2013). Nutritional composition of the pumpkin seed cultivated from selected regions in Kenya. Journal of Hort Letters. 3: 135 - 139

Lestari B. and Meiyanto E. (2018) A Review: The Emerging Nutraceutical Potential of Pumpkin Seeds Indones. J. Cancer Chemoprevent., 9(2), 92-101

Natural Institute of Health (NIH) (2019). Vitamin AConsumer. Office of Dietary Supplements. http://lods.od.nih.gov

Özden TA, Gökçay G, Cantez S M. , Durmaz Ö, Halim İ, Beyhan Ö and Günay S (2015). Copper, zinc and iron levels in infants and their mothers during the first year of life: a prospective study. BMC Pediatrics 15:157

Payne, W. J. A. (1990). An Introduction to Animal Husbandry in the Trophics. Longman Publishers Singapore Pp 92-110.

Qamar A.S., Mafia A. and Rizwan S (2019). Nutritional and Therapeutics Importance of the pumpkin Seed. Biomedical Journal of Science and Technology Research 21 (2). BJSTR.MS.ID.003586

Reilly O S, Griffin WL and Fisher NL (2002). Igneous zircon: Trace element composition as an indication of source of rock type. Contribution to Minerology143 (8), 602-622

Ró zyło K. (2014) Wheat bread with pumpkin (Cucurbita maxima L.)pulp as a functional food product. Food Technol. Biotechnol.;52:430-438.

Rodriguez-Amaya, Delia B. and Kimura, Mieko (2004). Harvestplus Handbook for Carotenoid Analysis. HarvestPlus Technical Monograph 2. Washington, DC

Thompson. A. Akinnifesi*, A. Olonisakin, M. A. Ibrahim, A.O. Adeola (2017). Comparative Analysis of Water melon (Citrullus lanatus), Pumpkin (Cucurbita pepo) and Fluted Pumpkin (Telfairia occidentalis) Grown in Nigeria for Physicochemical Properties and Fatty Acids Profile. ChemTech Journal Vol. 12 , pp 34 - 44 ISSN: 0794-8417

Wei Li, Patrict Simmons, Doug Shrader, Timothy J. Herriman, Susie Y. Dai (2013). Microwave plasma-atomic emission spectroscopy as a tool for determination of cupper, iron, manganese and zinc in animal feed and fertilizer. Talanta 112:43-48

Yoshida H, Tomiyama Y, Kita S and Mizushina M (2005) Roasting effects on fatty acid distribution of triacylglyerols and phospholipids in the kernels of pumpkin (Cucurbita spp) seeds. Journal of the Science of Food and Agriculture. Society of Chemical Industry. 85: 2061-2066 
BAJOPAS Volume 13 Number 2, December, 2020 